\title{
Government Policy in the Development of Duck Business in Pinrang Regency, South Sulawesi Province
}

\author{
Siti Nurlaelah¹, Sitti Nurani Sirajuddin'1, Nurhapsah², Nurul Magfirah ${ }^{3}$ \\ ${ }^{1}$ Department of socio economics, Faculty of Animal Science, Hasanuddin University \\ ${ }^{2}$ Department of Agribusiness, Faculty of Agriculture, Muhammadiyah University of Pare-Pare \\ ${ }^{3}$ Student of Department of Agribusiness, Faculty of Agriculture, Hasanuddin University
}

Correspondence Author: Aulia Nurul Hikmah, Agribusiness Study Program, Graduate School Hasanuddin University, Makassar, Indonesia Email: aulianurulhikmah@gmail.com, aulianurulhikmah@pasca.unhas.ac.id

Received date: 28 August 2019, Accepted date: 2 December 2019, Online date: 31 December 2019

Copyright: (C) 2019 Aulia Nurul Hikmah et al., This is an open-access article distributed under the terms of the Creative Commons Attribution License, which permits unrestricted use, distribution, and reproduction in any medium, provided the original author and source are credited.

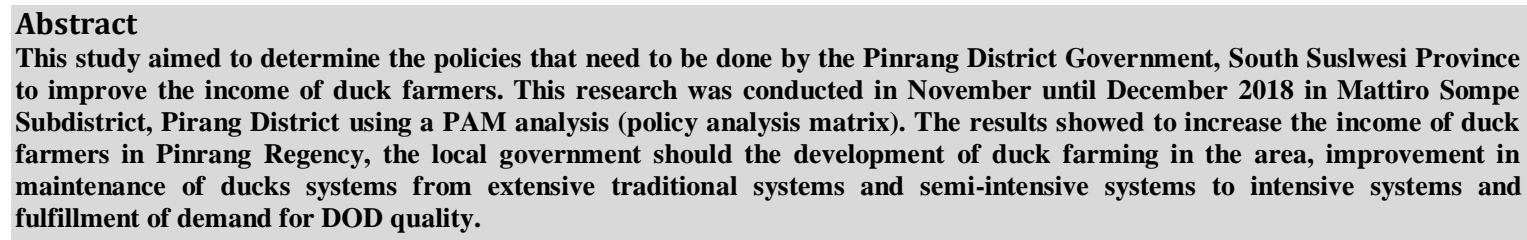

Keywords: policy, development, duck, business

\section{INTRODUCTION}

At present, the business in the field of animal husbandry has very potential opportunities, especially in duck farming [1] and [2]. Because one of the quite developed poultry businesses in Indonesia is the business of duck farming. Although not as popular as chicken, ducks have considerable potential as a producer of eggs and meat. When compared to other poultry, ducks have the advantage of being immune to disease. Therefore duck farming business has a smaller risk relatively. In Indonesia, ducks are one of the livestock commodities that have economic value and high potential, both as a source of animal protein and as an additional source in supporting family life.

The contribution of ducks to national egg production is quite significant, which as the second largest contributor after purebred chicken, with domestic duck egg production around 245 thousand tons/ year. Besides the size of the eggs which are bigger than chicken eggs, ducks are easy to maintain, easy to adapt to local conditions and are part of the life of rural farming communities. Broiler ducks is one type of cattle that produce meat. Broiler duck's meat production continues to increase as well as an increase in the population of broiler ducks in Indonesia. In Pinrang Regency, it is widely known that it is one of the centers of duck business development because Pinrang Regency is an area that most of its area consists of paddy fields so it is very suitable for developing duck farming. Duck meat's production in Pinrang Regency is 15.215 tons[2]. The need for duck's meat continues to increase, and even some restaurants, cafes and tent stalls in urban areas have a lot of serving fried duck, roast duck and duck satay as superior menu[3] Therefore, it is necessary to know the policies that need to be done by the local government of Pinrang Regency in order to developing the business of duck farming.

\section{RESEARCH METHODS}

The data was obtained from primary research data which described the condition of the research variable, namely the level of profit obtained by traders which maintain an intensive system broiler business in Mattiro Sompe Sub-District, Pinrang Regency. The study was conducted in November to December 2018.

The data analysis method used is the Policy Analysis Matrix (PAM). In this study, the PAM method is used to conduct an economic study of duck meat business. PAM can also be used to analyze this broiler duck business activity, as a system which includes handling, processing, and marketing 
Table 1. Identity Divergences in the Policy Analysis Matrix

$$
\begin{array}{l|l|l}
\text { Income } & \text { Cost } & \text { Profit }
\end{array}
$$

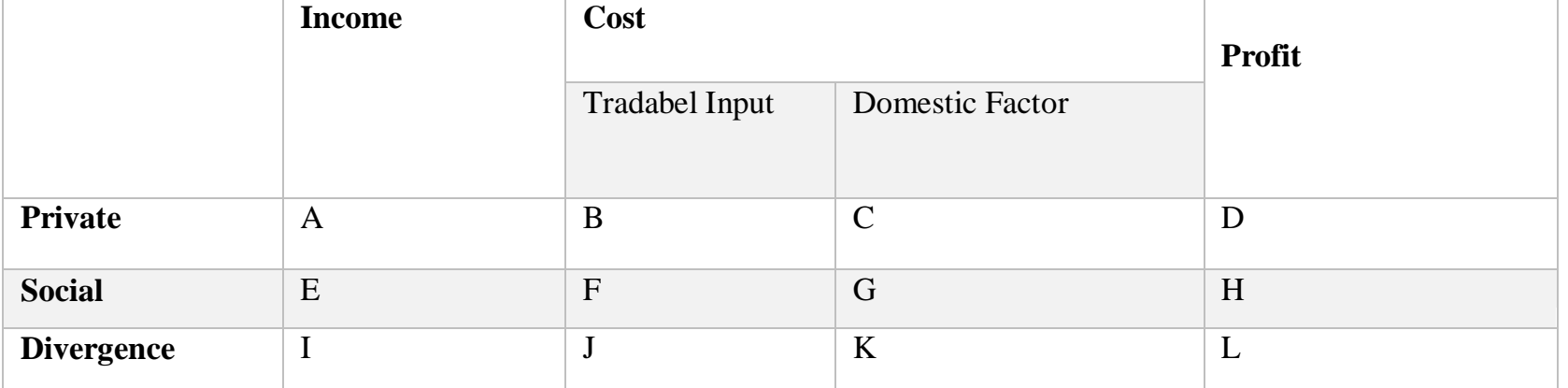

In the third row, each column contains the difference between values calculated based on private prices (first row) and values calculated based on social prices (second row). If market failure does not have a large effect, the difference is caused by policy intervention.

\section{DISCUSSION}

Input and Result of Policy Analysis Matrix

The following is a general description of duck meat business contained in Mattiro Sompe Sub-District, Pinrang Regency

Table 2. Policy Analysis Matrix Duck Development Mattiro Sompe Sub-District Pinrang Regency.

\begin{tabular}{|l|l|l|l|l|}
\hline & Income & Tradabel Input & Domestic Factor & Profit \\
\hline Privat & $34,125,000$ & $20,745,000$ & $1,916,500$ & \\
\hline Social & $23,100,000$ & $16,076,000$ & $2,506,400$ & $11,463,500$ \\
\hline Divergence & $11,025,000$ & $4,669,000$ & $-589,900$ & $4,517,600$ \\
\hline
\end{tabular}

Based on the results of the PAM analysis above, it shows that income has a positive effect on the broiler business in Mattiro Sompe Sub-District Pinrang Regency. The total income is derived from the sale of broiler ducks. In the tradeble input also obtained a positive divergence, but at the factual level in the field (private) input prices are far greater than the price of social inputs, this is because the maintenance time is quite different from private and social, this is in line with the opinion of[3],[4] and[5] said that the basis in the calculation of costs, include: (1) the number of livestock kept, (2) the maintenance system that is applied, (3) the cage material used, (4) the area of land cultivated, (5) the location of the farm, ( 6) the type of feed given, (7) the strength of the cage and equipment, (8) the length of production/maintenance and (9) the overhead which is an unexpected cost. This is also due to the different DOD prices between private and social prices. At private prices the DOD price is IDR. 6.500/head while the social price of IDR. 5.500, this is because DOD prices at private prices are obtained from traders who usually bring the DOD outside Pinrang Regency which is usually imported from Sidrap Regency, so the price is higher. Whereas at the social price, DOD is obtained from farmers in one farming group, so the price is relatively cheap.

Other tradable inputs are factors of production in the form of feed, medicine and vitamins, fuel, electricity and transportation showing a positive divergence where other factors of production in the broiler business in Mattiro Sompe SubDistrict Pinrang Regency is higher than the social comparison value. This is influenced by the cost of feed due to duck meat business in Mattiro Sompe Sub-District Pinrang Regency is higher than the feed used by social comparison. In the broiler business in Mattiro Sompe Sub-District Pinrang Regency takes 70 days to maintain while in the meat duck business in Jombang, East Java takes 35 days so that the cost of feed is different, and the private price is higher than the social price. In addition, this is also influenced by the prices of medicine and vitamins where private prices are higher than social prices. At social prices only use medicine and not use vitamins. Whereas the private price uses both.

In the domestic factor there is a negative divergence, this shows that management has not been efficient in the use of labor, even though labor costs in Mattiro Sompe Sub- District Pinrang Regency is cheaper than social labor costs. On the capital side, privately owned capital is far lower than social capital. This is due to the fact that the business of privately owned duck farming is still being developed as a part-time business with modest capital, although basically there has been an increase from previous maintenance system. Whereas social development has been developed on a larger business scale with larger and more efficient business capital.

Positive divergence in the broiler business at Mattiro Sompe Sub-District Pinrang Regency is also shown in the business profit gained. Higher profits are obtained from private with social comparison. This is because the sale of broiler ducks is more expensive than the comparison factor. The expensive broiler ducks on the private sector are also caused because the live weight of the duck is higher than the social price. 
Matrix Policy Analysis Ratio for broiler ducks in Mattiro Sompe Sub-District Pinrang Regency for Nominal Protection Coefficient on Output (NPCO) is 1, 48 it means that the output obtained in broiler ducks in Mattiro Sompe Sub-District Pinrang Regency is $48 \%$ higher compared to the NPCO social comparison.

Profibality Coefficient, which is the ratio between private and social profits, which is 2,54 it means that it is two and a half times more profitable for broilers in Mattiro Sompe Sub-District Pinrang Regency compared to social comparison. If viewed from the Domestic Resource Cost Ratio of 0, 11 it means that the duck meat business in the Mattiro Sompe Sub-District of Pinrang Regency will be more efficient if it uses domestic resources.

SRP value is 0,301 for broiler business in Mattiro Sompe Sub-District Pinrang Regency. A positive SRP value means that broiler producers incur a 30,1\% lower production cost for the broiler business.

The EPC value is 1, 91 it means that the government's policy on input-output causes the farmer to get an additional profit of $191 \%$ for the broiler business. Government policies have a positive impact on farmers.

\section{Government Policy Recommendations}

The government policy on the broiler business in Mattiro Sompe Sub-District Pinrang Regency has a positive impact on farmers so it needs to be maintained or increased again. The steps that need to be taken is the need for development of livestock sub-sector in Indonesia in an effort to meet food needs including the need for animal protein, especially meat ducks, which is increasing in line with the increasing population and public awareness to improve nutrition, especially animal protein. The nutritional content of livestock products and processed products to date is known to have a better value than the nutritional content of plant origin. In order to achieve the goal of animal husbandry development to meet nutritional needs, livestock development at this time needs to be directed at the development of more advanced farms through a regional approach, the use of appropriate technology and the application of new foundations, namely efficiency, productivity and sustainability.

Another local government policy that is needed to improve the maintenance system from traditional extensive system and semi-intensive system to intensive systems. Traditional management cannot be sustained anymore due to many factors including the shrinking of paddy fields as a duck grazing area after harvesting paddy rice and the conversion of functions into industrial, housing and trade zones, the more difficult it is to get hog labor because of the increasing employment in other sectors. Changes in maintenance system from extensive and semi-intensive system to incentives will affect the performance of ducks at all the age levels. Positive influence, ducks will be healthier and more efficient in converting feed into food, while negative effects occur, growth is too fast, quickly becomes fat because of reduced activity and more feed is needed and will certainly lead to waste if it is not followed by increased high production [6] and [7]

The next step that needs to be taken in addressing production inequality and demand for DOD, meat and duck eggs is to fulfill the shortage of quality DOD demand. Quality DOD production can be carried out on-farm at UPT nurseries and out-farm at duck nurseries in the seed source area managed by the private sector and community farmers. Human resource support that masters the science of duck breeding, government budget support, research institutions and universities, organizational management support and good nursery infrastructure facilities and others are input to the success of quality DOD production.

The regional autonomy policy needs to be anticipated by the regional government apparatus, especially in regencies/cities that are the spearhead of development, so that regencies/cities can improve themselves in exploring all potentials both natural resources potential and human resource potential. Thus, the potential of natural resources and human resources in the area can be utilized optimally for the benefit of regional development and community welfare.

Seeing the economic potential of duck business that has a high ability to generate profits, the duck business is expected to be able to become the main business that can sustain people's lives and create jobs for the community, especially rural communities.

\section{CONCLUSION}

Broiler duck development in Pinrang Regency is feasible to be developed. The value of B/C ratio for the broiler business in Mattiro Sompe Sub-District of Pinrang Regency is 1, 51 it means that the duck business in Pinrang Regency is profitable compared to the business in comparison. Local government policy that is the development of duck farming in an area, improvement in maintenance duck's system from extensive traditional system and semi-intensive system to intensive systems and fulfillment of demand for DOD quality.

\section{REFERENCES}

[1]Intan, Harizt dan Sa’ad Gumbira. 2001. Manajemen Agribisnis. Ghalia Indonesia. Jakarta.

[2] Sirajuddin, S. N., Nurlaelah, S., Amrawaty, A., Amrullah, T., Rohani, S. and Saleh, I. M. 2017. Relationship Between Farmers Characteristic and Income from Beef Cattle with The Traditional Profit-Sharing. American-eurasian journal of sustainable Agriculture 11(5):29-34.

[3]Astawan. 2007. Manajemen Pemasaran. Jakarta: Rajawali Press.

[4] Sirajuddin, S.N., Hastang, V.N. Lestari, Rosmawaty. 2019. Livestock ecology research on institution and traditional sharing systems in cattle farms. Eurasia J Biosci. 13 : 239-244

[5] SN Sirajuddin Sirajuddin, S.N., A. Asnawi, I.Rasyid, A.Mangalisu, Masnur. 2016. Competitiveness of Beef Cattle Fattening in Kulo Subdistrict, Sidrap District South Sulawesi. Advances in Environmental Biology Journals. Vol. 10. No.1. Page 171-175. 
[6] Rusli. 2009. Kualitas Telur Itik Asin (Studi Kadar Air, Organoleptik Dan Daya Simpan). Fakultas Peternakan dan Perikanan, Universitas Muhammadiyah Malang.

[7] Pearson, S, Carl Gotsch dan Sjaiful Bahri. 2005. Aplikasi Policy Analysis Matrix Pada Pertanian Indonesia. Jakarta: Penerbit Yayasan Obor Indonesia. 